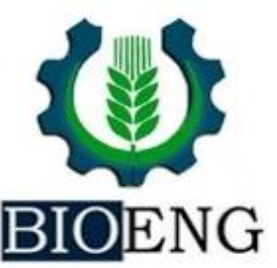

\title{
FACTORS THAT AFFECT BROILER PRODUCTION
}

\section{M. dos S. Baracho ${ }^{1}$ I. de A. Nääs ${ }^{1,2^{*}}$, D. J. de Moura ${ }^{1}$, N. D. da S. Lima ${ }^{1}$, A. F. Cordeiro ${ }^{2}$, R. Baracat T.R. da Silva ${ }^{2}$}

${ }^{1}$ State University of Campinas, College of Agricultural Engineering, Campinas, Brazil

${ }^{2}$ Graduate Course in Production Engineering, Paulista University, São Paulo, Brazil

Article history: Received 18 November 2017; Received in revised form 10 December 2017; Accepted 15 December 2017; Available online 27 December 2017.

\begin{abstract}
Brazil occupies a privileged position worldwide in poultry farming. The economic activity is recognized as necessary for the country's GDP and also has a significant climatic diversity. Because of this, different types of aviaries were and still are built in the national territory. The objective of this study was to present a systematic review of the factors that have an impact on the intensive production of broiler chicken based on the scientific publications since the year 2000. The literature review showed a constant evolution and the knowledge about the form of housing that best expresses the genetics of birds. It was found that the thermal environment, air quality and other factors related to the housing of broiler chickens significantly imply in their performance.
\end{abstract}

Keywords: thermal comfort, ambient cooling, flock density, broiler genetic strains.

\section{FATORES QUE AFETAM A PRODUÇÃO DE FRANGOS DE CORTE}

O Brasil ocupa uma posição privilegiada em todo o mundo na produção de frangos de corte. A atividade econômica é reconhecida como necessária para o PIB do país, que também possui uma expressiva diversidade climática. Por isso, diferentes tipos de aviários foram e ainda são construídos no território nacional. O objetivo deste estudo foi apresentar uma revisão sistemática dos fatores que têm impacto na produção intensiva de frangos de corte com base nas publicações científicas desde o ano 2000. A revisão da literatura mostrou evolução constante e conhecimento sobre a forma de alojamento que melhor expressa a genética dos frangos. Verificou-se que o ambiente térmico, a qualidade do ar e outros fatores relacionados ao alojamento de frangos de corte impactam expressivamente no desempenho.

Palavras chaves: conforto térmico, refriamento de ambiente, linhagens genéticas de frangos.

\footnotetext{
renilza.naas@docente.unip.br; irenilza@gmail.com
} 


\section{INTRODUCTION}

The Brazilian production of broilers has grown in remarkable numbers in the last 50 years, and this was only possible because there was an increase in domestic meat consumption and exports (MENDES, 2014). Brazil occupies a privileged position of the $2^{\text {nd }}$ largest producer in the world's poultry production, an essential activity for the country's economy. Brazil is standing out as the leader in exports $(581,558$ tons in 2013) and the third largest producer of chicken meat $(12,645,1$ thousand tons in 2012) (UBA, 2013; UBABEF, 2014).

Today, large numbers of female breeders are housed in the country's farms, founding a dynamic, highly competitive segment in which the product of the best yield influences the systemic chain that includes everything from inputs to production on the farms, and processing in the industry. The high technological level achieved by the national poultry industry placed this economic activity in an advantaged position about other livestock activities developed in Brazil, with an

\section{SYSTEMS FOR BROILER PRODUCTION}

Brazil has significant climatic diversity and, therefore, different types of aviaries were and still are built in the national territory (Nääset al., 2014). The facilities must ensure an environment of thermal comfort that allows the animal to express its full genetic potential (NASCIMENTO et al., 2014). Animal facilities are the result of all the external and internal conditions that affect the development, responses, and growth of the animals housed in them. As per ESTRADA-PAREJA et al. (2007), the factors affecting the animal environment can be physical (light, noise, construction, and equipment), social (density), and technical factors (Temperature, relative humidity, air movement, thermal radiation, among others). In poultry farming, it is known that international productivity level, compared to the most updated countries in the world (LIMA et al., 1995). Broiler production is a business that requires reasonable investment whose return is proportional to the producer's ability to maximize sources of loss (Rizzi, 1993). The food and management, and health are also important issues during the production.

As the animal production systems are modified, efforts were made to develop techniques and tools to assist in animal production monitoring (Abreu, 2010; Abreu \& Abreu, 2011). The intensification of automation and state-of-the-art technologies brought the increase in the variability of the thermal environment of the houses, with consequent variability in the performance indexes (Carvalho, 2012). All these innovations introduced in studies of broiler production have allowed researchers to deepen knowledge of the factors that interfere in the rearing environment, leading to higher precision in the corrections and adjustments of these systems (Abreu \& Abreu, 2011).

substantial losses in production occur mainly in the final stages of rearing. Those failures are due to thermal stress that reduces performance indexes and increases bird mortality (Abu-Dieyeh, 2006). Morrow (2001) raised the ambient temperature and found that this action leads to a decrease in the bird's ability to dissipate heat resulting in a circular and respiratory imbalance. Thus, the ideal bird productivity depends on the effective temperature, which reflects the combination of the effects of dry bulb temperature, relative humidity, solar radiation and wind speed (MOURA, 2001). One of the ways to predict if the environment causes stress due to heat is through the ITU - temperature and humidity index, and the same was adapted for 
chickens by CHEPETE et al. (2005) and through the ITGU - black globe temperature index and humidity.

Light intensity, distribution, color and duration of light affect the performance and well-being of the batch. Light management is an advantageous and low-cost technique in the production of broiler chicken and is a tool to be used within a management program (RUTZ et al., 2014).

Modern aviaries are carefully lit to reduce cannibalism, bird movement, and energy costs (ARAÚJO et al., 2013). Furthermore, proper positioning of light sources and their distribution in the shed encourages birds to seek food, water, and heat during the rearing phase. For Santana et al. (2014) the use of LEDs has been highlighted in aviculture because it presents energy savings and provides viability of the breeding process.

Studies on the welfare of broilers (Moura et al., 2006; Bessei, 2006) indicate that the themes related to the thermal and aerial environment, as well as the quantity and intensity of light of the sheds, are more influential in the response of birds. Among the most important strategies to prevent loss of productivity due to caloric stress is the control of luminosity in aviaries (Linet et al., 2006; Blatchford et al., 2009). Alvino et al. (2009) suggest exposing the birds to higher luminous intensities to increase their wellbeing, as light increases the behavioral rhythms and the comfort behaviors of birds.

\section{ENVIRONMENT IMPACT IN POULTRY PRODUCTION}

The production environment plays a fundamental role in modern poultry farming, which seeks to achieve high productivity, in physical space and relatively short time (Amaral et al., 2011). Chicken is a homeothermic animal, that is, it maintains the body temperature constant. To keep homeothermic, the rate of heat transfer to the environment should be equal to the rate of heat production (Bruce \& Clark, 1979). Birds, as well as pigs, do not sweat in response to a temperature rise (Ingram, 1974; Harrison, 1995), and both growing pigs and chicks have relatively little plumage and thus little thermal insulation. Therefore, birds tend to respond more to changes in the thermal environment than other species of domestic animals, which can be offset by behavioral responses such as grouping of chicks.

For Damasceno et al. (2010) and Amaral et al. (2011) thermal factors, mainly represented by air temperature relative humidity, thermal radiation, and air velocity, are those that affect birds more directly, as they can compromise their homeothermic. The facilities must ensure the maintenance of homeothermic, to maintain animal thermal comfort and ensure the well-being in the production (Nascimento, 2011).

Birds are also endothermic animals, which means that they can increase the amount of body temperature by generating considerable amounts of heat inside their tissues rather than relying solely on heat gained directly from their surroundings (Bligh \& Johnson, 1973). According to these authors, thermoregulation characteristics are similar in birds and other large groups of homeothermic animals and mammals. The mechanisms of thermal regulation seek to maintain the temperature inside the stable body (Bruce \& Clark, 1979). To achieve this, however, the temperature of the peripheral tissue can vary considerably, causing fluctuations in the average temperature of the body.

The thermoneutral zone is related to an ideal thermal environment, where birds find perfect conditions to express their best productive characteristics (Furtado et al., 2003). The zone of thermal comfort or thermoneutral varies according to the species and within the same species. In the birds, the 
thermoneutral zone changes with its genetic constitution, age, sex, body size, weight, diet, physiological state, previous exposure to heat, a variation of ambient temperature, radiation, humidity and air velocity (Cassuce, 2011).

Inadequate rearing conditions affect the production of broiler chickens, and it is necessary to improve the houses and balance the management to overcome the harmful effects arising from some critical environmental factors (Furtado et al., 2003). The constructive typology of the houses, associated with the local macroclimate, the topography, and the surrounding vegetation, influences the internal microclimate conditions. Associate to these factors, internal temperatures, ventilation and flow, speed and relative humidity of the air, can alter the emission of greenhouse gases, becoming an additional concern with the broader environmental aspect (Miragliotta, 2005).

In environments considered comfortable, the birds present higher productivity and better performance parameters (Medeiros et al., 2005). Therefore, excess heat in the housing environment can be detrimental to bird performance. Wherefore, there is a high influence of the typology on the environmental conditions inside the houses, and the technical norms must be observed to obtain good thermal conditioning (Furtado et al., 2003). According to Yahav et al. (2004), the more precise quantification of the surface temperature of the birds the more accurate is the estimation of the heat exchanges of broilers. The proportion of the animal body that is at the same temperature as the interior of the body may vary, depending on environmental conditions. As a consequence, of the vasoconstriction, the temperature of the extremities, and skin of the animal are more influenced by the external heat in a cold environment. If the ambient temperature is high, vasodilation increases peripheral blood flow, making the body's distribution of temperature more uniform (Ingram \& Mount, 1975). The thermal comfort of an animal cannot be determined solely by heat unless all other conditions are standardized (Ingram \& Mount, 1975). Many factors influence the air temperature range perceived by animals as comfortable. The thermal environment is composed of the various environmental factors that affect the heat transfer between the animal and its surroundings. It is not fixed, in the sense that the perception of the environment varies from animal to animal.

An increase in air movement will increase heat losses by conduction and make the animal feel cold; while the presence of a radiant heater will result in a net gain of heat by radiation and make the bird feel warm. Thermal insulation of the floor also affects the rate of heat loss by conduction. Thus, at a given temperature, the same animal may be hot, if it is exposed to solar radiation, or cold if it is wet, in the wind and the shade. Also, the number of animals in pen or the house affects the contact area when the animals are grouped, making them more resistant to cold in a larger group. The level of food intake influences the production of metabolic heat so that the same animal can respond differently to the same environment, depending on the feeding program used (Ingram \& Mount, 1975).

To accurately assess the effect of the environment on broilers, one must consider all environmental factors as well as the animal's characteristics and peculiarities of the production system. The thermal environment can be characterized by air temperature, radiant temperature, air velocity, air humidity. For broilers, temperature values between 32 and $34{ }^{\circ} \mathrm{C}$ are considered comfortable for the first week (Cony \& Zoche, 2004; Oliveira et al., 2006; Pauli et al., 2008).

According to Bridi (2011) at least three primary conditions must be observed for optimal thermal comfort from a physiological point of view: 1 . Consider that 
there is a caloric balance between the animals and the environment; Establishment of an essential relationship between the average temperature of the skin and the activity of the animal in the comfort zone; and, 3. Establishment of water loss through evaporation and the activity of the animal in the comfort zone.

The evolution of the studies on the rearing environment in broilers has reached remarkable levels concerning information on air quality, the thermal, acoustic and luminous environment in the different stages of broiler breeding (Silva \& Vieira, 2010). These factors directly influence the comfort and welfare condition of the birds, affecting their productivity (Ponciano et al., 2011). According to Moura et al. (2006) and Santos et al. (2009), thermal comfort inside poultry

\section{FINAL REMARKS}

The evolution of the scientific publications on broiler housing has generated crucial scientific information about air quality, the thermal, acoustic and luminous environment in the different stages of breeding. Also, knowledge about the

\section{REFERENCES}

ABPA. Associação Brasileira de Proteína Animal. Available at: www.abpa.org.br Accessed Jun 242017.

ABREU, V.M.N.; ABREU, P. G. Os desafios da ambiência sobre os sistemas de aves no Brasil. Revista Brasileira de Zootecnia, 2011, v.40, p.1-14. (supl. especial), 2011.

ABREU, P.G. Desafios da pesquisa frente aos novos sistemas de produção. Avicultura Industrial, edição 1189, n.5, p.20-29, 2010.

ABU-DIEYEH, Z.H.M. Effect of high temperature per se on growth performance farms is a highly significant factor, since poor conditions considerably affect the production of broiler chickens. Estimating comfort conditions is a desirable feature in models that determine the thermal wellbeing of broiler chickens. Situations classified as hazardous actions may result in the expenditure of economic resources avoiding productive losses (Nascimento et al., 2011).

Welfare issues in poultry production are related to the thermal and aerial environment, as well as the quantity and intensity of light of the houses. These subjects are addressed, for instance, in the studies in roof insulation, being, however, more influential in the response of the birds when extremes of temperatures occur inside the rearing environment (Lima et al., 2003).

behavior and performance of the lineages in various forms of rearing systems has also been generated by the international and Brazilian research groups, helping the development of the sector.

of broilers. Int. Journal Poultry Science, v.5, n.1, p.19-21, 2006.

ALVINO, G.M.; ARCHER, G.S.; MENCH, J.A. Behavioural time budgets of broiler chickens reared in varying light intensities. Applied Animal. Behaviour Science, v:118, p.54-61, 2009.

AMARAL, A.G.; YANAGI JUNIOR, T.; LIMA, R. R.; TEIXEIRA, V.H.; SCHIASSI, L. Efeito do ambiente de produção sobre frangos de corte sexados criados em galpão comercial. Arquivo Brasileiro de Medicina Veterinária e Zootecnia, 63(3), 649-658, 2011. 
ARAUJO, F.E.; NÄÄS, I. A.; ROSA, C.O.R.; BORILLE, R. Utilização do diodo emissor de luz (LED) na produção de frangos de corte. Enciclopédia Biosfera, v.9, n.17; p. 2577, 2013.

BESSEI, W. Welfare of broilers. World's Poultry Science Journal, v.62, n.3, p.45566, 2006.

BLATCHFORD, R.A.; KLASING, K.C.; SHIVAPRASAD, H.L.; WAKENELL, P.S.; ARCHER, G.S.; MENCH, J.A. The effect of light intensity on the behavior, eye and leg health, and immune function of broiler chickens. Poultry Science, v. 88, p.20-28, 2009.

BLIGH, J.; JOHNSON, K.G. Glossary of terms of thermal physiology. Journal of Applied Physiology, v. 35, p.941 961, 1973.

BRIDI, A. N. Instalações e Ambiência em Produção Animal. Available at: http://wp.ufpel.edu.br/bioclimatologiaanimal /files/2011/05/InstalacoeseAmbienciaemPro ducaoAnimal.pdf. Accessed on: May 20 2013.

BRUCE, J.M.; CLARK, J. J. Models of heat production and critical temperature for growing pigs. Animal Production, v. 28, p. 363-369, 1979.

CARVALHO, R. H. Influência de diferentes modelos de instalações de frango de corte e ambiência de luz pré-abate sobre o bemestar animal e qualidade de carne. 2012. 124 f. Dissertação (Mestrado em Tecnologia de Alimentos) - Universidade Tecnológica Federal do Paraná, Londrina, 2012.

CASSUCE, D. C. Determinação das faixas de conforto térmico para frangos de corte de diferentes idades criados no Brasil. Tese (Doutorado) Viçosa (MG): Universidade Federal de Viçosa; 2011.
CHEPETE, H.J.; CHIMBOMBI, E.; TSHEKO, R. Production performance and temperature-humidity índex of Cobb 500 broiler reared in open-side naturally ventilated houses in Botswana. Proceedings of the 2005 ASAE Annual Meeting. Paper n. 701P0205, Beijing, China, 2005.

CONY, A.V.; ZOCCHE, A. T. Manejo de frangos de corte. Produção de frangos de corte. (ed.). MENDES, A.; NÄÄS, I. DE A.; MACARI, M. Campinas: FACTA, 2004. $356 p$.

DAMASCENO, F. A.; TADAYUKI, Y.J.; LIMA, G. R.R.; COSTA, R. C.; MORAES, S.R.P. Avaliação do bem-estar de frangos de corte em dois galpões comerciais climatizados. Ciência Agrotecnologia, vol.34, p. 1031-1038, 2010.

ESTRADA-PAREJA, M.M.; MARQUEZGIRON, S.M.; RESTREPO-BETANCU, L.F. Caracterización de las propiedades del aire húmedo (Sicrometría) del microclima de la hacienda Vegas de la Clara (nordeste antioqueño). Revista Colombinana Ciências Pecuárias, v.20, p.339-342, 2007.

FURTADO, P.V.; AZEVEDO, P.V.; TINÔCO, I.F. Análise do conforto térmico em galpões avícolas com diferentes sistemas de acondicionamento. Revista Brasileira de Engenharia Agrícola e Ambiental, v.7, n.3, p.559-564, 2003.

INGRAM, D.L.; MOUNT, L.E. Man and animals in hot environments. New York, Springer-Verlag, $1975.185 \mathrm{p}$.

LIMA, J.; SIQUEIRA, S.; ARAUJO, D. Relato Setorial. Avicultura, 1995.

LIMA, K.R.S.; ALVES, J.A.K.; ARAUJO, C.V.; MANNO, M. C.; JESUS, M.L.C.; FERNANDES, D.L.; TAVARES, F. Avaliação do Ambiente Térmico Interno em Galpões de Frango de Corte com Diferentes 
Materiais de Cobertura na Mesorregião Metropolitana de Belém. Revista Ciência Agrária, n. 51, p.37-50, 2003.

LIN, H.; JIAO, H. C.; BUYSE, J.; DECUYPERE, E. Strategies for preventing heat stress in poultry. World's Poultry Journal, v.62, n.1, p.71-85, 2006.

MEDEIROS, C.M.; BAÊTA, F. C.; OLIVEIRA, R. F. M.; TINÔCO, I. F.; ALBINO, L. F. T.; CECON, P. R. Efeitos da temperatura, umidade relativa e velocidade do ar em frangos de corte. Engenharia na Agricultura 2005. v. 13, p.277-286, 2005.

MENDES, A. A Cadeia avícola brasileira. 2ed. Campinas: Facta v. 1, p. 3-12, 2014.

MIRAGLIOTTA, M. Y. Avaliação das Condições do Ambiente Interno em dois Galpões de Produção Comercial de Frangos de Corte, com Ventilação e Densidade Populacional Diferenciados. 244p. Tese (Doutorado) - Universidade Estadual de Campinas, Campinas. 2005.

MOURA, D. J. Ambiência na produção de aves de corte. In: SILVA, I.J.O. (Ed.) Ambiência na produção de aves em clima tropical. Piracicaba - SP, v.2, p.75-149, 2001.

MOURA, D. J.; NÄÄS, I. A.; PEREIRA, D. F.; SILVA, R. B. T. R.; CAMARGO, G. A. Animal welfare concepts and strategy for poultry production: a review. Revista Brasileira de Ciência Avícola, v.8, n.1, p.137-148, 2006.

MORROW C. Poultry management, heath and disease in hot climates. JORDAN, F.; PATTISON, M.; ALEXANDER, D.; FARAGHER, T. Poultry Disease. 5th Ed., London, W. B. Sauders. 2001.

NÄÄS, I. A.; GARCIA, R. G.; BARACHO, M. S.; BICHARA, T. Ambiência para frango de corte. Ambiente térmico para avicultura. 2ed.Campinas: Facta, v. 1, p. 111-132, 2014.

NASCIMENTO, G. R.; PEREIRA, D. F.; NÄÄS, I. A.; RODRIGUES, L. H. A. Índice fuzzy de conforto térmico para frangos de corte. Engenharia Agrícola, v. 31, n. 2, p.219-229, 2011.

NASCIMENTO, G. R.; NÄÄS, I. A.; BARACHO, M. S.; PEREIRA, D. F.; NEVES, D. P. Termografia infravermelho na estimativa de conforto térmico de frangos de corte. Revista Brasileira de Engenharia Agrícola e Ambiental, v.18, p. 658-663, 2014.

OLIVEIRA, R. F. M.; DONZELE, J. L.; LOBÃO, M. L. T.; FERREIRA, R. A.; VAZ, R. G. M. V.; CELLA, O. S. Efeitos da temperatura e da umidade relativa sobre o desempenho e o rendimento de cortes nobres de frangos de corte de 1 a 49 dias de idade. Revista Brasileira Zootecnia, v.35, p.797803, 2006.

PAULI, D. G.; SILVA, J. N.; VIGODERIS, R. B.; TINÔCO, I. F.; IORIO, V. O.; GALVARRO, S. F. S. Desenvolvimento de um Sofware para dimensionamento de sistemas de ventilação e resfriamento evaporativo em instalações avícolas climatizadas. Engenharia na Agricultura, v.16, p.167-179, 2008.

PONCIANO, P.F.; LOPES, M.A.; YANAGI JUNIOR, T.; FERRAZ, G.A.S. Análise do ambiente para frangos por meio da lógica fuzzy: uma revisão. Archivos de Zootecnia, v. 60 p. 1-13, 2011.

RIZZI, A. T. Mudanças tecnológicas e reestruturação da indústria alimentar: o caso da indústria de frangos no Brasil. 1993. 194 p. Tese (Doutorado) - Instituto de Economia, Universidade Estadual de Campinas. Campinas, SP. 1993. 
RUTZ, F.; SILA, F. H. A.; NUNES, J. K. Fundamentos de um programa de luz para frango de corte. 2ed.Campinas: Facta, v. 1, p. 111-132. 2014.

SANTOS, P. A.; BAETA, F. C, TINÔCO I. F.; ALBINO, L. F. T.; CECON, P. R. Ventilação em modos túnel e lateral em galpões avícolas e seus efeitos no conforto térmico, na qualidade do ar e no desempenho das aves. Revista CERES, v.56, n.2, p.172-180, 2009.

SANTANA MR, GARCIA, RG, NAAS IA., PAZ, IC, CALDARA, FR, BARRETO B. Light emitting diode (LED) use in artificial lighting for broiler chicken production. Engenharia Agrícola, v. 34, n.3, 422-427, 2014.

SILVA, I. J. O.; VIEIRA, F. M. C. Ambiência animal e as perdas produtivas no manejo pré-abate: o caso da avicultura de corte brasileira, Archivos de Zootecnia, v.59, p. 113-131, 2010.

UBA-União Brasileira de Avicultura. Relatório Anual. Available at: www.abef.com.br/uba/relatorios_anuais.ph Accessed on May 202013.

YAHAV, S.; STRASCHNOW, A.; LUGER, D.; SHINDER. D.; TANNY, J.; COHEN, S. Ventilation, sensible heat loss, broiler energy, and water balance under harsh environmental conditions. Poultry Science, v. 83, p.253-258, 2004. 